\title{
Interspecific hybridization of Begonia semperflorens (section Begonia) with B. pearcei (section Eupetalum) for introducing yellow flower color
}

\author{
Yen-Ming Chen, Masahiro Mii* \\ Graduate School of Horticulture, Chiba University, Matsudo, Chiba 271-8510, Japan \\ *E-mail: miim@faculty.chiba-u.jp Tel:+81-47-308-8852 Fax:+81-47-308-8720
}

Received December 22, 2011; accepted January 24, 2012 (Edited by M. Otani)

\begin{abstract}
The interspecific hybrids were successfully obtained from different cross combinations between 12 cultivars (8 diploids and 4 tetraploids) of Begonia semperflorens (section Begonia) and B. pearcei (section Eupetalum) by in vitro culture of mature and immature seeds on MS medium (Murashige and Skoog 1962) containing $30 \mathrm{gl}^{-1} \mathrm{sucrose} 0.1 \mathrm{mgl} \mathrm{l}^{-1}$ $\alpha$-naphthylacetic acid, $0.1 \mathrm{mgl}^{-1}$ 6-benzyladenine, $2.5 \mathrm{gl}^{-1}$ gellan gum, and $10 \mathrm{mgl}^{-1}$ gibberellic acid. Although all the cross combinations yielded plantlets at the plantlet yielding efficiency of 0.1-2.6/ovary in the culture of mature seeds, some cross combinations gave higher plantlet yields up to 5.7/ovary when immature seeds of 12-16 days after pollination were cultured. The plantlets obtained were confirmed their hybridity through flow cytometric analysis and random amplified polymorphic DNA analysis. In the crosses using diploid B. semperflorens hybrids with normal genome combinations (SP genome) and chromosome doubled hybrids with SSPP genome were obtained, whereas only normal triploid hybrids (SSP genome) were produced from the cross with tetraploid B. semperflorens. Some flowered hybrids of SP and SSP genomes showed intermediate flower colors between the parents such as apricot, cream and light yellow colors, suggesting the expression of yellow flower color of $B$. pearcei. Although the pollen fertility of those interspecific hybrids was sterile, they are expected to utilize as the important breeding materials to produce yellow flower cultivars of B. semperflorens after restoring the fertility by chromosome doubling treatments.
\end{abstract}

Key words: Begonia, embryo rescue, flower color, interspecific hybridization, spontaneous chromosome doubling.

Begonia semperflorens Link and Otto is the most popular member of cultivated begonias, widely used in the horticultural business according to the advantages such as dwarf plant height with a maximum of $30 \mathrm{~cm}$, nice branching characters, strong disease resistance, and perpetual flowering expect for the season with frosty weather. B. semperflorens was ranked as the fourth largest bedding plant in the United States in 2009, following to pansy (Viola $\times$ wittrockiana Gam.), impatiens (Impatiens wallerana Hook. f.) and petunia (Petunia $\times$ hybrida Vilm.). Its total output value reached 36 million U.S. dollars (USDA 2010). Although B. semperflorens has red, pink, and white flower colors, it lacks yellow and orange colors to date despite of its long history of breeding. $B$. semperflorens has been considered to result from the interspecific crossing between $B$. cucullata Willd. and B.schmidtiana Regel within the same section Begonia (Dewitte et al. 2009; Horn 2004; Tebbitt 2005). Moreover, Hvoslef-Eide and Munster (2006) also indicated that the $B$. semperflorens might be resulted from the crosses with other wild species, which is unclear. However, $B$. semperflorens is still difficult to cross with other wild species, which contain yellow or orange flower color.

In the genus Begonia, some species such as B. pearcei, B. lutea, B. xanthina, and B. flaviflora have yellow flower color (Tebbitt 2005) and they have been importantly used for the breeding of many cultivars. The most famous instance is $B$. 'Tamakihada', which is the progeny of $B$. 'Orange Rubra' $\times B$. pearcei, being the uniquely canelike type with the yellow flower color (Tebbitt 2005). In addition, many tuberous begonias contain the consanguinity of $B$. pearcei which has yellow flower color. Therefore, $B$. pearcei seems to play a critical role to create novel cultivars with yellow flower colors. $B$. pearcei is a native species to South Africa and belongs to the section Eupetalum (Tebbitt 2005). Since B. pearcei belongs to tuberous group and is not tolerant to a humid and sultry weather, it becomes weak, non-flowering, and dormant during such an unfavorable weather season. In contrast, B. semperflorens could be a potent germplasm to improve the disadvantageous characters of such tuberous begonias through interspecific hybridization since it

Abbreviations: BA, 6-benzyladenine; DAP, days after pollination; ER, embryo rescue; $\mathrm{GA}_{3}$, gibberellic acid; NAA, $\alpha$-naphthylacetic acid; PYE, plantlet yield efficiency; RAPD, random amplified polymorphic DNA.

This article can be found at http://www.jspcmb.jp/ 
Table 1. The efficiency of progeny production among different cross combinations between $B$. semperflorens and B. pearcei by culturing mature seeds in vitro.

\begin{tabular}{|c|c|c|c|c|c|c|c|}
\hline Maternal donor & $\begin{array}{c}\text { No. of flowers } \\
\text { pollinated }\end{array}$ & $\begin{array}{c}\text { Fruit set } \\
(\%)^{\mathrm{a}}\end{array}$ & $\begin{array}{l}\text { No. of ovaries } \\
\text { cultured }\end{array}$ & $\begin{array}{l}\text { No. of ovaries } \\
\text { yielding plantlet }\end{array}$ & $\begin{array}{l}\text { No. of plants } \\
\text { obtained }\end{array}$ & $\begin{array}{l}\text { Plantlet yield } \\
\text { efficiency }^{\mathrm{c}}\end{array}$ & $\begin{array}{l}\text { Pollen } \\
\text { fertility }\end{array}$ \\
\hline 'Monza-Pink' (2x) & 21 & 100 & 21 & 5 & 47 & 2.23 & $91.2 \mathrm{a}$ \\
\hline 'Monza-White' (2x) & 20 & 90 & 18 & 4 & 14 & 0.77 & $85.8 \mathrm{~b}$ \\
\hline 'Monza-Salmon orange' $(2 \mathrm{x})$ & 19 & 100 & 15 & 2 & 5 & 0.33 & $86.6 \mathrm{~b}$ \\
\hline ‘Monza-Apple blossom’ (2x) & 20 & 100 & 20 & 2 & 15 & 0.75 & $83.3 \mathrm{bc}$ \\
\hline 'Sprint-Pink' $(2 \mathrm{x})$ & 22 & 100 & 20 & 9 & 40 & 2 & $70.3 c$ \\
\hline 'Queen-Pink' $(2 \mathrm{x})^{\mathrm{e}}$ & 26 & 54 & 14 & 8 & 37 & 2.64 & - \\
\hline 'Queen-White' $(2 \mathrm{x})^{\mathrm{e}}$ & 13 & 54 & 7 & 2 & 15 & 2.14 & - \\
\hline 'Queen-Red' $(2 \mathrm{x})^{\mathrm{e}}$ & 10 & 40 & 4 & 2 & 5 & 1.25 & - \\
\hline 'Monza-Coral' (4x) & 23 & 100 & 23 & 2 & 33 & 1.43 & $46.3 \mathrm{de}$ \\
\hline 'Varsity-Pink imp' (4x) & 24 & 92 & 20 & 2 & 4 & 0.2 & $17.9 \mathrm{~g}$ \\
\hline 'Varsity-White' (4x) & 22 & 100 & 21 & 4 & 13 & 0.61 & $49.0 \mathrm{~d}$ \\
\hline 'Varsity-Bicolor' (4x) & 22 & 100 & 22 & 1 & 3 & 0.13 & $23.1 \mathrm{f}$ \\
\hline
\end{tabular}

${ }^{a}$ Percentage of capsules obtained after 30 days. ${ }^{b}$ Each ovary was inoculated on a plate individually. ${ }^{\mathrm{c}}$ No. of plants obtained/No. of ovaries cultured. ${ }^{\mathrm{d}}$ Means with the same letters in a column are not significantly different by Duncan's multiple range test at $5 \%$ level. ${ }^{\text {e }}$ Double flower cultivars.

contains excellent characters such as short internode, nice branching, resistance to diseases, tolerance to hot weather and continuous flowering.

For the breeding of important flower crops like as rose, chrysanthemum, carnation, lily and orchids, interspecific hybridization has efficiently been employed to create abundant varieties in addition to intraspecific hybridization. Although interspecific hybridization can increase the variations in some crops, it always encountered to the barriers like as failure of fertilization and embryo abortion in conventional breeding method. To solve the latter problem, embryo rescue technique has efficiently been employed to increase the chance to obtain the hybrids. Recently, successful results on interspecific hybridization have been reported in some flower crops such as Hemerocallis (Li et al. 2009), Hydrangea (Reed et al. 2008), Chrysanthemum (Sun et al. 2010), Primula (Amano et al. 2006; Hayashi et al. 2007a, 2007b, 2009), Dianthus (Nimura et al. 2003), Lilium (Chi 2000), Melaleuca (Liu et al. 2006), and Chocolate cosmos (Oku et al. 2008) with the aid of embryo rescue techniques. In the present study, we report the usefulness of embryo rescue technique to obtain the hybrids between $B$. semperflorens and B. pearcei.

\section{Materials and methods}

\section{Plant materials}

Twelve cultivars of Begonia semperflorens belonging to the 4 series of cultivars, which are described in Table 1 , and one strain of $B$. pearcei were used in this study. Nine single flower type cultivars of Begonia semperflorens were kindly provided by Sakata Seed Co. (Yokohama, Japan). Three double flower type cultivars of B. semperflorens and B. pearcei were purchased from a local market. During the experimental period, all the plants were cultivated as pot plants in the greenhouse, which was kept under natural light conditions, whereas the temperature was kept higher than $18^{\circ} \mathrm{C}$ but below $30^{\circ} \mathrm{C}$.

\section{Interspecific hybridization}

In this study, twelve cultivars of $B$. semperflorens were used as maternal parents, and one clonally propagated strain of $B$. pearcei was used as pollen parent. In B. semperflorens, all the male flowers were removed before anthesis and female flowers were covered by paraffin paper bags to prevent unexpected pollination. Dehisced anthers containing fresh pollen were harvested from the male flower at anthesis and directly pollinated by touching the stigma of female flowers at the day of anthesis of the maternal parent. The pollinated flowers were then covered again with the bags. All cross-pollinations were made during the winter of 2009-2010.

\section{In vitro seed sowing and embryo rescue}

In the initial experiment, mature ovaries were collected 30 days after pollination (DAP) before dehiscence. In the embryo rescue experiment, the immature ovaries at different DAP (4, $8,12,16$ and 20 days) were used to determine the efficiency of interspecifc hybridization. The mature/immature ovaries were surface-sterilized with $70 \%$ ethanol for $1 \mathrm{~min}$ and then with $1 \%$ sodium hypochlorite solution for $15 \mathrm{~min}$ containing two drops of Tween 20, followed by 3 times of rinsing with sterile distilled water. After surface sterilization, ovary walls were carefully removed with the tip of forceps and the placental tissues with seeds/ovules were carefully excised from ovaries. In the case of mature ovaries harvested at $30 \mathrm{DAP}$, seeds were released from placental tissue onto the medium by rolling the placenta on the medium, after which the placenta was removed. In the culture of younger ovaries $(4,8,12,16$ and 20 days), however, it was difficult to release all of the seeds and hence the placental tissue was kept on medium for the culture of attaching seeds/ovules after the rolling treatment with the released seeds/ovules. Irrespective of the difference in releasing treatment, they were cultured on embryo rescue (ER) medium, which consisted of full strength MS medium (Murashige and 
Skoog 1962), $0.1 \mathrm{mgl}^{-1} \alpha$-naphthylacetic acid (NAA), $0.1 \mathrm{mgl}^{-1}$ 6-benzyladenine (BA), $10 \mathrm{mgl}^{-1}$ gibberellic acid $\left(\mathrm{GA}_{3}\right)$, $2.5 \mathrm{gl}^{-1}$ gellan gum and $30 \mathrm{gl}^{-1}$ sucrose. Seedlings showing abnormal growth obtained by interspecific hybridization were transferred onto root induction medium, which consisted of the full strength MS medium with $30 \mathrm{gl}^{-1}$ sucrose, $2.5 \mathrm{gl}^{-1}$ gellan gum and $0.1 \mathrm{mgl}^{-1} \mathrm{NAA}$. The $\mathrm{pH}$ of media was adjusted to 5.8 with $\mathrm{KOH}$ before autoclaving. All cultures were maintained at $24 \pm 2^{\circ} \mathrm{C}$ with $16 \mathrm{~h}$ photoperiod provided by cool white fluorescent tubes $\left(35 \mu \mathrm{mol} \mathrm{m}{ }^{-2} \mathrm{~s}^{-1}\right)$. The progenies were acclimatized and transferred to the greenhouse to investigate the morphological traits during the summer, 2010.

\section{Measurement of relative nuclear DNA content using flow cytometry}

Relative nuclear DNA contents were compared between parents and progenies by using flow cytometry (Partec $\mathrm{GmbH}$, Münster, Germany). Young leaf segments (about $0.5 \mathrm{~cm} \times 0.5 \mathrm{~cm})$ were chopped with razor blade in $200 \mu \mathrm{l}$ Solution A (Plant High Resolution DNA kit type P, Partec $\mathrm{GmbH}$ ), then added with $1 \mathrm{ml}$ DAPI solution [10 $\mathrm{mM}$ Tris$\mathrm{HCl}, \mathrm{pH} 7.5$, containing $50 \mathrm{mM}$ sodium citrate, $2 \mathrm{mM} \mathrm{MgCl}_{2}$, $1 \%(w / v)$ PVP K-30 (Polyvinylpyrrolidone K-30) (Wako Pure Chemical Industries Ltd.), $0.1 \%$ (v/v) Triton X-100, $2 \mathrm{mgl}^{-1}$ DAPI (4',6-diamidino-2-phenylindole dihydrochloride)] and incubated for $1 \mathrm{~min}$ to stain the cell nuclei. The well-mixed solution was filtered through $45 \mu \mathrm{m}$ nylon mesh to remove the debris and used for the analysis. After preliminary confirmation of chromosome numbers in several cultivars of B. semperflorens 'Sprint-Pink' was selected as a diploid cultivar and used as an intrernal standard for flow cytometric analysis of the parental plants and interspecific hybrids. Peak position for nuclear DNA content of 'Sprint-Pink' was adjusted to channel number 50, relative DNA contents of other cultivars of B. semperflorens and $B$. pearce $i$ were determined as relative values provided that nuclear DNA content of 'Sprint-Pink' was 2 units.

\section{DNA extraction and random amplified polymorphic DNA (RAPD) analysis}

Total DNA was isolated following the protocol of Kopperud and Einset (1995) which was applied previously for isolating begonia DNA. Briefly, about $2 \mathrm{~g}$ of leaf tissue was ground into a fine powder by using liquid nitrogen, transferred into a centrifuge tube, added with $25 \mathrm{ml}$ of T10E10 washing solution (10 mM Tris-HCL, $10 \mathrm{mM}$ EDTA, $\mathrm{pH} 8.0$ ), vortexed for $10 \mathrm{~s}$, and centrifuged for $10 \mathrm{~min}$ at $8000 \mathrm{rpm}$ at $4^{\circ} \mathrm{C}$. Afterwards, the supernatant was discarded, and the DNA was extracted by CTAB method (Murray and Thompson 1980).

Among the arbitrary oligonucleotide 10-mer primers of Operon Biotechnologies (Tokyo, Japan), OPE-03 $\left(5^{\prime}\right.$-CCAGATGCAC- $\left.3^{\prime}\right)$ was used for amplification by polymerase chain reaction (PCR) by 39 repeating thermal cycles $\left(4 \mathrm{~min}\right.$ at $94^{\circ} \mathrm{C}, 30 \mathrm{~s}$ at $94^{\circ} \mathrm{C}, 30 \mathrm{~s}$ at $35^{\circ} \mathrm{C}$, and $1 \mathrm{~min}$ $72^{\circ} \mathrm{C}$ ). After completion of amplification, the amplified DNA mixture was loaded on a $2 \%$ agarose gel in TAE buffer, and run for $50 \mathrm{~min}$ at $100 \mathrm{~V}$. The gel was photographed under UV light to compare the RAPD patterns of the putative hybrids with maternal and pollen parents.

\section{Morphological comparison and pollen fertility}

The leaf and flower characters were measured to compare the difference between both parents and hybrids. Pollen fertility was assessed by staining with aceto-carmine on at least 200 pollen grains in each observation for every genotype with 5 replications. The results were analyzed with Duncan's multiple range test to compare the significant difference at $5 \%$ level.

\section{Results}

Fruit set and cross compatibility of $B$. semperflorens $\times B$. pearcei

In the interspecific crosses with $B$. pearcei, using 12 cultivars in four series, all the single flower cultivars of B. semperflorens used as female parents including $2 \times$ and $4 \times$ ones showed $90 \%$ or higher ratios of fruit set 30 DAP, whereas 3 double flower type cultivars belonging to 'Queen' series gave around 50\% of fruit set ratio (Table 1).

When the mature ovaries collected 30 DAP were cultured on ER medium, most of harvested seeds with the crimpy seed surface did not germinate during the culture period. In contrast, well-developed seeds with plumpy surface germinated within 2 weeks, in which the radicle emerged through seed coat primarily and the cotyledon grew later. All the 12 cultivars consisting of 8 diploids and 4 tetraploids yielded plantlets with the efficiency of 0.2-2.64 per ovary (Table 1). Among single flower type cultivars, 'Monza-Pink' gave the highest efficiency of plantlet yield (PYE), 2.23 per ovary, followed by 'Sprint-Pink', and 'Monza-Coral'. On the other hand, 3 double flower type cultivars showed higher efficiency of plantlet yield than single flower type cultivars with the highest PYE in 'Queen-Pink' (2.64).

Since 30 DAP seemed to be late for rescuing abortive hybrid embryos, we chose four cultivars of $B$. semperflorens 'Monza-Pink' (2x), 'Varsity-Pink imp' $(4 \mathrm{x})$, 'Sprint-Pink' $(2 \mathrm{x})$ and 'Queen-Pink' $(2 \mathrm{x})$ for the cross with $B$. pearcei and tested the PYE by culturing ovaries of 4, 8, 12, 16 and 20 DAP (Table 2). In all the four cultivars of $B$. semperflorens used, the highest PYE was obtained at 12-16 DAP, whereas PYE was reduced in the ovary culture with 20 DAP in all the cultivars. Although PYE obtained in the culture of 12-16 DAP for both tetraploid 'Varsity-Pink imp' (2.66) and diploid 'Sprint-Pink' (5.66) was higher than that of 30 DAP, other two cultivars, diploid 'Queen-Pink' and diploid 'Monza-Pink' gave slightly lower PYE in the culture of 12-16 DAP (Tables 1, 2).

During the embryo rescue culture, germination of immature seeds occurred after 15 days of culture (Figure 
Table 2. The effect of different DAP on the embryo rescue between B. semperflorens and B. pearcei.

\begin{tabular}{|c|c|c|c|c|c|}
\hline Maternal donor & $\begin{array}{l}\text { Days after } \\
\text { pollination }\end{array}$ & $\begin{array}{l}\text { No. of ovaries } \\
\text { cultured }\end{array}$ & $\begin{array}{c}\text { No. of ovaries yielding } \\
\text { plantlets }^{\mathrm{a}}\end{array}$ & $\begin{array}{c}\text { No. of plantlets } \\
\text { obtained }\end{array}$ & $\begin{array}{l}\text { Plantlet yielc } \\
\text { efficiency }^{\mathrm{b}}\end{array}$ \\
\hline \multirow[t]{5}{*}{ 'Monza-Pink' (2x) } & 4 & 3 & 0 & - & - \\
\hline & 8 & 3 & 0 & - & - \\
\hline & 12 & 3 & 2 & 3 & 1.00 \\
\hline & 16 & 3 & 1 & 4 & 1.33 \\
\hline & 20 & 3 & 0 & - & - \\
\hline \multirow[t]{5}{*}{ 'Varsity-Pink imp' (4x) } & 4 & 3 & 0 & - & - \\
\hline & 8 & 3 & 0 & - & - \\
\hline & 12 & 3 & 3 & 8 & 2.66 \\
\hline & 16 & 3 & 2 & 7 & 2.33 \\
\hline & 20 & 3 & 2 & 2 & 0.66 \\
\hline \multirow[t]{5}{*}{ 'Sprint-Pink' (2x) } & 4 & 3 & 1 & 3 & 1.00 \\
\hline & 8 & 3 & 1 & 1 & 0.33 \\
\hline & 12 & 3 & 3 & 17 & 5.66 \\
\hline & 16 & 3 & 3 & 16 & 5.33 \\
\hline & 20 & 3 & 3 & 10 & 3.33 \\
\hline \multirow[t]{5}{*}{ 'Queen-Pink' (2x) } & 4 & 3 & 0 & - & - \\
\hline & 8 & 3 & 0 & - & - \\
\hline & 12 & 3 & 2 & 6 & 2 \\
\hline & 16 & 3 & 1 & 4 & 1.33 \\
\hline & 20 & 3 & 2 & 1 & 0.33 \\
\hline
\end{tabular}

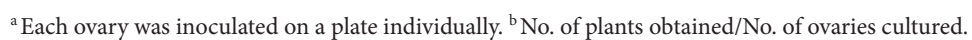

1A), but they developed into abnormal cotyledonless seedlings 30 days after inoculating on ER medium (Figure 1B). From the top of these abnormal embryos, rosette shoots initiated to regenerate 45 days after inoculating on ER medium (Figure 1C). Then, those small shoots were separated from the top of abnormal embryo and successfully rooted on root induction medium (Figure 1D). About 2.5 months, these putative hybrid plantlets were transferred to greenhouse after acclimatization, in which they grew normally (Figure $1 \mathrm{E}, \mathrm{F})$ till flowering.

\section{Confirmation of hybridity by using flow cytometry to measure the relative nuclear DNA content}

Totally 163 progenies were obtained from all the 12 cross combinations between $B$. semperflorens and $B$. pearcei. They were subjected to flow cytometry analysis to evaluate the relative DNA contents of both parental donors and their hybrids (Table 3, Figure 2). The relative DNA contents of $B$. semperflorens diploid cultivars, tetraploid cultivars, and B. pearcei were 2, 4 and 8.97 units, respectively. In the cross combinations between diploid cultivars of $B$. semperflorens (SS genome) and B. pearcei (PP genome), 7 cross combinations yielded only the expected progenies with the intermediate value of DNA content between two parents as 5.48 units (SP genome, Figure 2A). However, cross combinations using 'Queen-Red' yielded both 2 normal diploid plants and 3 unexpected plants with twice the DNA content of the normal hybrid presumed to be chromosomedoubled hybrid with SSPP genome (10.97 units, Figure
2B). In all the 4 crosses using tetraploid cultivars of $B$. semperflorens (SSSS genome), all the progenies displayed the intermediate value (SSP genome, Figure 2C), ca. 6.48 units.

\section{Hybridity analysis by using RAPD markers}

Among the 16 randomly selected primers tested, OPE-03 was found to give the specific bands for $B$. pearcei and each cultivar of $B$. semperflorens. When RAPD analysis was performed for the randomly selected progenies by using both diploid and tetraploid cultivars of $B$. semperflorens as female parents, all of them showed the specific bands for both $B$. pearcei and B. semperflorens by using the primer OPE-03. Thus, the hybridity of those progenies were confirmed (Figure 3).

\section{Morphological characters and pollen fertility of the hybrids}

Leaf characters of B. semperflorens, B. pearcei and their putative hybrids are summarized (Figure 1G). Comparing with the green leaf color of female parents: $B$. semperflorens, $B$. pearcei used as a male parent had a dark purple color on the undersurface of the leaf. On the other hand, all the putative hybrids obtained deep green color on the surface, but dark purple on the undersurface, which is more similar to the leaf color of the $B$. pearcei. In contrast, the length and width of leaf, and blade aspect ratio of the hybrids are more alike $B$. semperflorens (data not shown).

After transfer the putative hybrids to the greenhouse, some of them produced flowers. In the hybrids between 

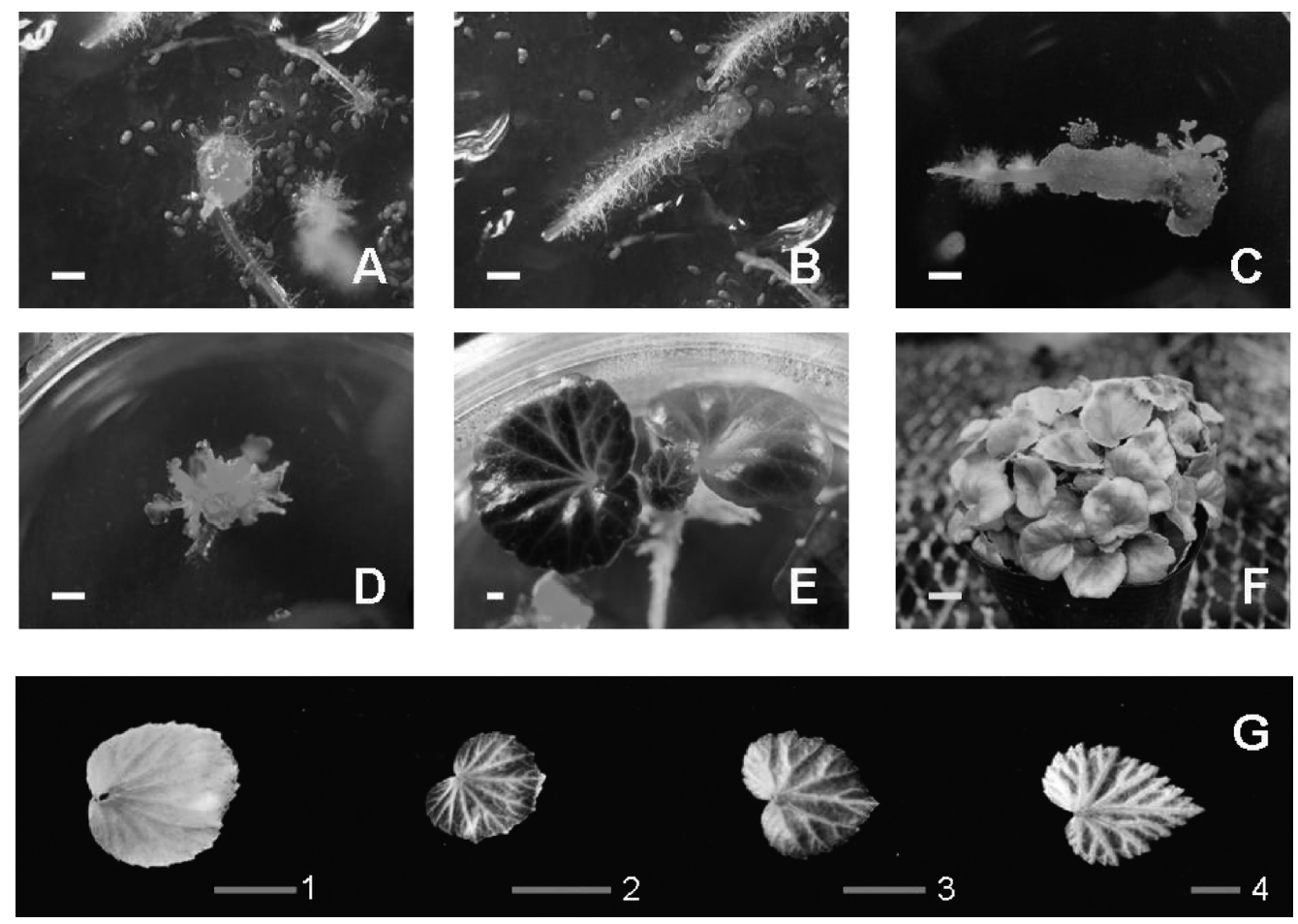

Figure 1. The regeneration of the hybrid between B. semperflorens and B. pearcei by utilizing the embryo rescue technology with ER medium (16th DAP). (A) Embryo generation from the immature seed 15 days after sowing. (B) Root elongation from abnormal cotyledon-less embryo 30 days after sowing. (C) Shoot regeneration from the top of abnormal embryo 45 days after sowing. (D) Shoots transferred to root induction medium after separation from the top of abnormal embryo. (E) The putative hybrid between the B. semperflorens and B. pearcei in vitro. Bar=0.2 cm. (F) Compact plant character of hybrid between B. semperflorens 'Sprint-Pink' and B. pearcei. Bar $=1 \mathrm{~cm}$. (G) The undersurface characteristics of the leaf blade in the hybrids between B. semperflorens and B. pearcei. 1: Female parent: B. semperflorens 'Sprint-Pink'. 2: Hybrid (SP) between the B. semperflorens 'Sprint-Pink' (2x) and B. pearcei. 3: Hybrid (SSP) between the B. semperflorens 'Monza-Coral' (4x) and B. pearcei. 4: Male parent: B. pearcei. Bar $=2.5 \mathrm{~cm}$.

Table 3. Flow cytometric analysis of the ploidy level and genome combination of hybrids in interspecific cross between B. semperflorens and B. pearcei.

\begin{tabular}{|c|c|c|c|c|}
\hline \multirow[b]{2}{*}{ Maternal donor } & No. of plants obtained ${ }^{a}$ & No. of plants analyzed & \multicolumn{2}{|c|}{ No. of plants } \\
\hline & $\begin{array}{l}\text { Expected gen } \\
\text { relative DN }\end{array}$ & $\begin{array}{l}\text { ombination \& } \\
\text { tent (units) }\end{array}$ & $\begin{array}{l}\text { Intermediate (SP) } \\
5.48 \text { units }\end{array}$ & $\begin{array}{l}\text { Chromosome-doubled } \\
\text { (SSPP) } 10.97 \text { units }\end{array}$ \\
\hline \multicolumn{5}{|c|}{ Diploid cultivars of $B$. semperflorens $(2 \mathrm{x}) \mathrm{SS}=2$ units } \\
\hline 'Monza-Pink' & 54 & 8 & 8 & 0 \\
\hline 'Monza-White' & 14 & 10 & 10 & 0 \\
\hline 'Monza-Salmon orange' & 5 & 5 & 5 & 0 \\
\hline 'Monza-Apple blossom' & 15 & 13 & 13 & 0 \\
\hline 'Sprint-Pink' & 87 & 40 & 40 & 0 \\
\hline 'Queen-Pink' & 48 & 30 & 30 & 0 \\
\hline 'Queen-White' & 15 & 12 & 12 & 0 \\
\hline \multirow[t]{2}{*}{ 'Queen-Red' } & 5 & 5 & 2 & 3 \\
\hline & \multicolumn{2}{|c|}{$\begin{array}{l}\text { Expected genome combination \& } \\
\text { Relative DNA Content (units) }^{\mathrm{b}}\end{array}$} & $\begin{array}{l}\text { Intermediate (SSP) } \\
6.48 \text { units }\end{array}$ & $\begin{array}{l}\text { Chromosome-doubled } \\
\text { (SSSSPP) } 12.97 \text { units }\end{array}$ \\
\hline \multicolumn{5}{|c|}{ Tetraploid cultivars of B. semperflorens ( $4 \mathrm{x})$ SSSS $=4$ units } \\
\hline 'Monza-Coral' & 33 & 23 & 23 & 0 \\
\hline 'Varsity-Pink imp' & 21 & 4 & 4 & 0 \\
\hline 'Varsity-White' & 13 & 10 & 10 & 0 \\
\hline 'Varsity-Bicolor' & 3 & 3 & 3 & 0 \\
\hline
\end{tabular}

\footnotetext{
${ }^{a}$ The hybrids examined were obtained from mature seed sowing method in the cross of diploid B. semperflorens and embryo rescue method in the cross with tetraploid B. semperflorens, respectively.
}

${ }^{\mathrm{b}}$ Pollen donor: $B$. pearce $\mathrm{PP}=8.97$ units. 

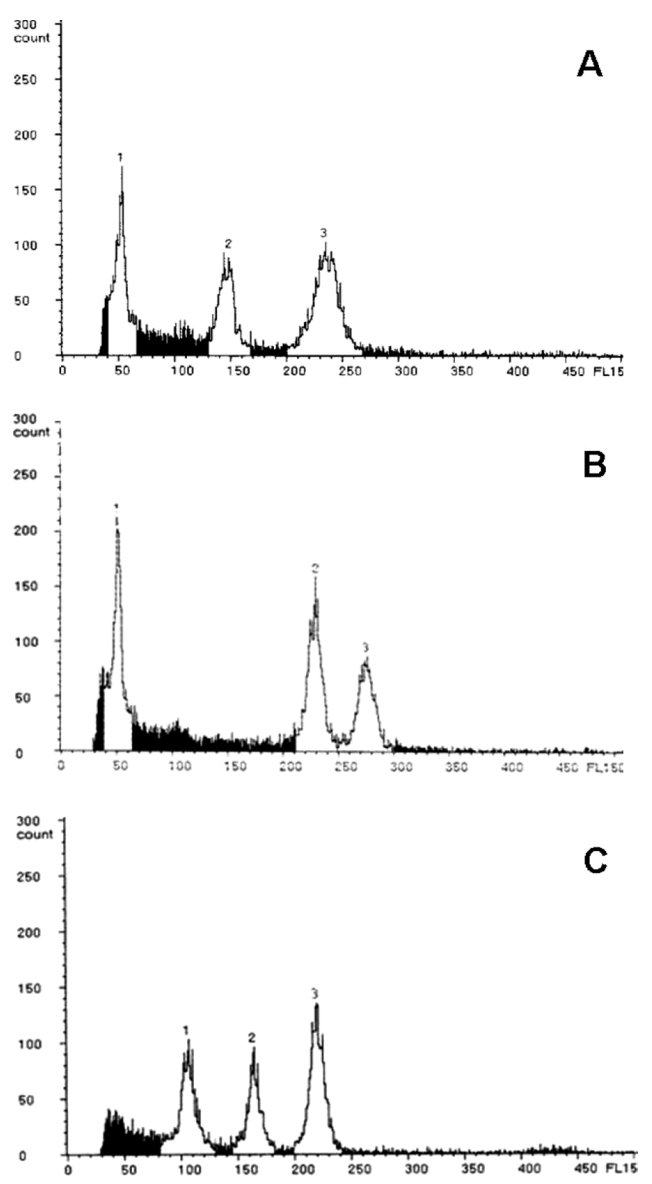

Figure 2. Relative DNA content estimated by flow cytometric analysis. (A) 1: B. semperflorens 'Sprint-Pink' (SS genome). 2: Hybrid (SP genome). 3: B. pearcei (PP genome). (B) 1: B. semperflorens 'QueenRed' (SS genome). 2: B. pearcei (PP genome). 3: Chromosome doubled hybrid (SSPP genome). (C) 1: B. semperflorens 'Varsity-White' (SSSS genome). 2: Hybrid (SSP genome). 3: B. pearcei (PP genome).

B. semperflorens 'Sprint-Pink' (Pink, Figure 4A) and B. pearcei (Yellow, Figure 4B), flowers of the hybrids showed different color variations including light yellow (Figure 4C), cream (Figure 4D), apricot (Figure 4E), and deep apricot (Figure $4 \mathrm{~F}$ ), which are expected to appear as intermediates between the flower colors of both parents (Figure 4).

The average pollen fertility was $83.5 \%$ in 5 diploid single flower cultivars of $B$. semperflorens, whereas only $34.1 \%$ in the 4 tetraploid cultivars of B. semperflorens. In contrast, both the diploid hybrids with SP genome (Figure 4D) and the triploid hybrid (SPP) had atrophied pollen showing no stainability with aceto-carmine.

\section{Discussion}

In the present study, we initially analyzed the ploidy difference of $B$. semperflorens cultivars used by flow cytometry before conducting interspecific hybridization with $B$. pearcei. The result indicated that they involved diploid, triploid and tetraploid as reported previously
(Horn 2002; Zeilinga 1962). Since triploid cultivars were confirmed to be sterile in our preliminary hybridization experiments, only diploid and tetraploid cultivars were used for the hybridization experiment. Although both tetraploid and single-flowered diploid cultivars showed high fruit set ratio (more than 90\%), double-flowered diploid cultivars showed around $50 \%$ of the ratio when they were used as female parents (Table 1). However, the difference in fruit set ratio did not correlate with the yield of the hybrid plants and double flower cultivars produced hybrids at almost comparable efficiencies with single flower cultivars (Table 1). These results suggest that main cause of the difficulty in producing interspecific hybrids between $B$. semperflorens and B. pearcei is different between double-flowered cultivars and single-flowered ones used as female parents: inhibition of fertilization in the former and abortion of hybrid embryo in the latter, respectively, although the reasons are unclear.

In our preliminary study, we failed to germinate the seeds collected at maturity obtained in this interspecific hybridization or to grow the seedlings in ex vitro condition. In the present study, therefore, we applied in vitro culture for safely rescuing both mature and immature seeds collected at different DAP. In in vitro culture of mature seeds, PYE was quite low despite of the high fruit set ratio: $0.1-1.4$ in tetraploids, $0.3-2.2$ in single flower diploids and 1.3-2.6/ovary in double flower diploid cultivars, respectively. Although PYE could be increased to some extent in some cultivars such as a tetraploid cultivar 'Varsity-Pink imp' (2.7/ovary) and a diploid cultivar 'Sprint-Pink' (5.7/ovary) by culturing immature ovules/seeds at 12-16 DAP, other 2 cultivars showed reduced efficiencies. These results suggest that in vitro embryo rescue culture is useful to obtain the interspecific hybrids of $B$. semperflorens with $B$. pearcei, but that optimum timing of the culture should be checked for achieving the maximum yield of the hybrids.

Introduction or creation of novel flower colors and flower types is always needed in the breeding of ornamental crops such as begonias, and interspecific hybridization has been recognized as a useful strategy for achieving this objective. Recently, many successful cases have been reported in the production of interspecific hybrids in various genera of ornamental crops such as Primula (Kato and Mii 2000; Kato et al. 2001), Kalanchoe (Izumikawa et al. 2008), Limonium (Morgan et al. 1998) and Chrysanthemum (Cheng et al. 2010). In Torenia fournieri (Endo 1962) and Lathyrus odoratus (Brouillard 1983; Hammett et al. 1994), interspecific hybridization has also been conducted for producing yellow flower hybrids, which resulted in either intermediate flower colors between the parents or entirely different colors from both parents. In the present study, we have confirmed the expression of yellow color of $B$. pearcei to some extent showing new flower colors such as apricot, 


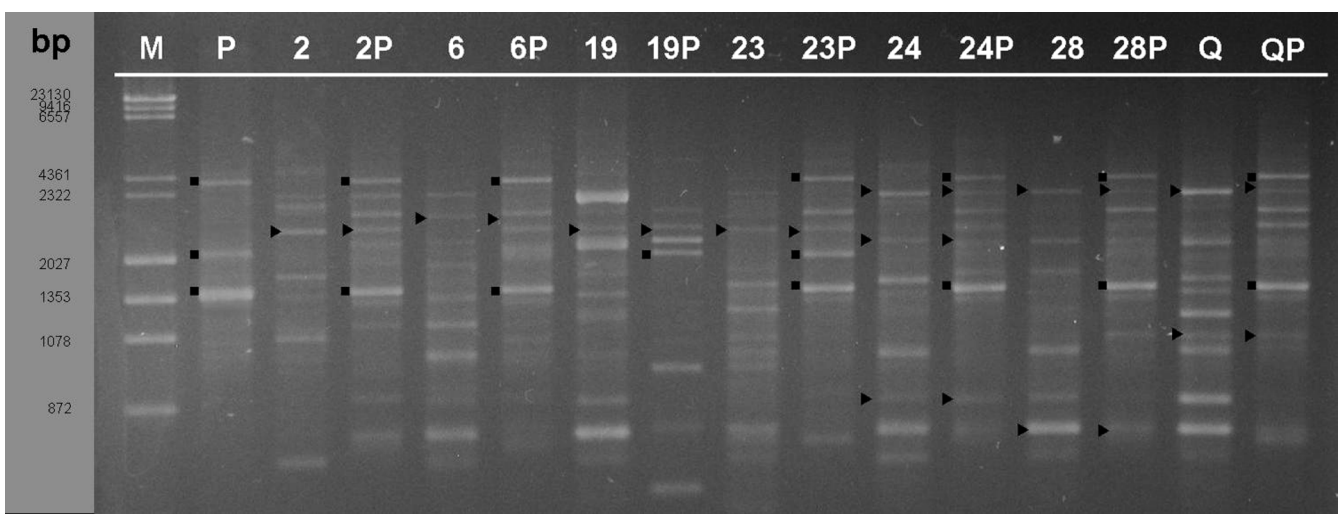

Figure 3. RAPD analysis for confirming the hybrids obtained from interspecific hybridization between B. semperflorens and B. pearcei. The primer OPE-03 was used. M: $\lambda$ DNA/HindIII+Фx174/HaeIII-digestion size marker. P: B. pearcei. 2: B. semperflorens 'Monza-Pink'. 6: B. semperflorens 'Varsity-White'. 19: B. semperflorens 'Sprint-Pink'. 23: B. semperflorens 'Varsity-Pink imp'. 24: B. semperflorens 'Monza-White'. 28: B. semperflorens 'Monza-Apple blossom'. Q: B. semperflorens 'Queen-Pink'. The hybrid of 2P, 6P, 19P, 23P, 24P, 28P, and QP were obtained from different cross combinations between B. semperflorens and B. pearcei. $\mathbf{\square}$ : The specific band of B. pearcei. $\mathbf{\Lambda}$ : The specific band of $B$. semperflorens.
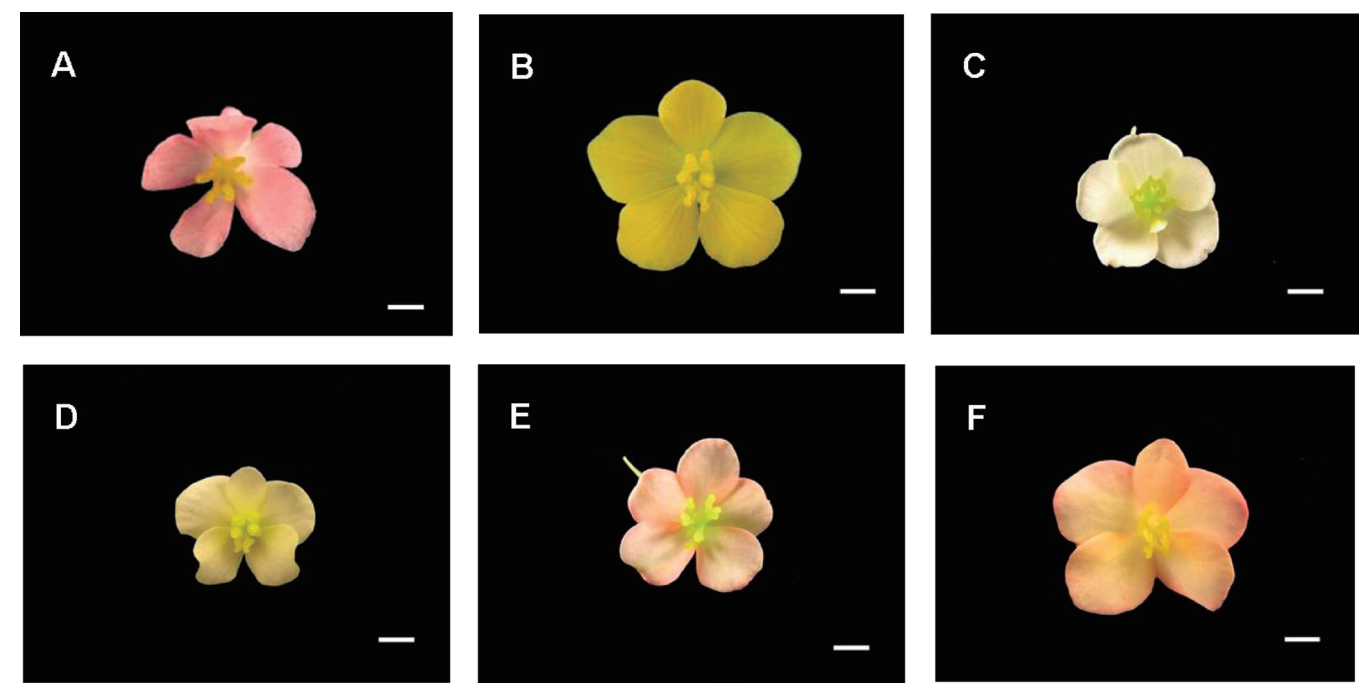

Figure 4. The flower characteristics of the hybrids between B. semperflorens and B. pearcei. (A) Female flower of material parent: B. semperflorens 'Sprint-Pink'. (B) Female flower of pollen parent: B. pearcei. (C)-(F) Female flower of the interspecific hybrids. Bar $=1 \mathrm{~cm}$.

light yellow in all the interspecific hybrid plants that bloomed already (Figure 4). Therefore, it is possible to utilize these hybrids as the breeding materials to create yellow or novel flower colors in B. semperflorens. Moreover, we also obtained some interspecific hybrids between double flower cultivars of $B$. semperflorens ('Queen' series) and B. pearcei. Although they have not yet flowered, they could also be utilized to produce double and yellow flowered B. semperflorens cultivars.

In the present study, we successfully produced diploid hybrids (SP genome) and triploid hybrids (SSP genome) from the cross combinations between different cultivars of $B$. semperflorens and B. pearcei. Except for these normally expected hybrids, 3 unexpected hybrids showing SSPP genome type were also produced, suggesting that spontaneous chromosome doubling occurred in these plants during embryogenesis or in vitro seedling development after germination. Although previous report (Dewitte et al. 2009) has indicated the occurrence of $2 \mathrm{n}$ pollen in $B$. pearcei, interspecific hybrids with unexpected ploidy level caused by the fertilization with the unreduced pollen of $B$. pearcei were not obtained in the present study.

In the genus Begonia, numerous cultivars have been produced through interspecific hybridization between relatively closely related species. However, it is rather difficult to produce hybrids between distantly related species belonging to the different sections and no successful studies have been reported on the production of the interspecific hybrids between $B$. semperflorens and $B$. pearcei. Our present success in this interspecific hybridization might be due to the application of embryo rescue techniques such as in vitro seed germination and immature ovule culture. Therefore, such simple in vitro techniques may powerfully be utilized to produce interspecific hybrids between distantly related species 
in the genus Begonia. In the present study, our main objective to produce interspecific hybrids between $B$. semperflorens and $B$. pearcei is to utilize them as the breeding materials to produce yellow flower cultivars of B. semperflorens. Unfortunately, however, all the hybrids with SP and SSP genomes so far flowered showed no pollen fertility, although varied abilities of seed production have previously been reported in the triploid hybrids (SSD genome) of Christmas Begonia produced by the cross between $B$. scotrana and $B$. dregei (Horn et al. 1976). The sterility of the interspecific hybrids has also been reported in various cross combinations of Begonia species (Peng and Chiang 2000; Peng and Chen 1991; Peng and Sue 2000; Peng and Ku 2009). Therefore, it is indispensable to produce amphidiploids by artificial chromosome doubling techniques for restoring the fertility. Recently, Dewitte et al. (2010) have succeeded to restore the pollen fertility in the male sterile hybrid of begonia by the treatment with trifluralin or $\mathrm{N}_{2} \mathrm{O}$. Since we have already obtained unexpectedly produced SSPP hybrids, it is necessary to confirm the fertility of these hybrids if they attain to the flowering stage. We are also trying to induce chromosome doubling in sterile SP and SSP hybrids with some mitotic inhibitors such as colchicine.

\section{References}

Amano J, Kato J, Nakano M, Mii M (2006) Production of intersection hybrids between Primula filchnerae and P. sinensis through ovule culture. Sci Hortic (Amsterdam) 110: 223-227

Brouillard R (1983) The in vivo expression of anthocyanin colour in plants. Phytochemistry 22: 1311-1323

Cheng X, Chen SM, Chen FD, Fang WM, Deng YM, She LF (2010) Interspecific hybrids between Dendranthema morifolium (Ramat.) Kitamura and D. nankingense (Nakai) Tzvel. achieved using ovary rescue and their cold tolerance characteristics. Euphytica 172: 101-108

Chi HS (2000) Interspecific crosses of lily by in vitro pollinated ovules. Bot Bull Acad Sinica (Taiwan) 41: 143-149

Dewitte A, Eeckhaut T, Van Huylenbroeck J, Van Bockstaele E (2009) Occurrence of viable unreduced pollen in a Begonia collection. Euphytica 168: 81-94

Dewitte A, Eeckhaut T, Van Huylenbroeck J, Van Bockstaele E (2010) Induction of $2 \mathrm{n}$ pollen formation in Begonia by trifluralin and $\mathrm{N}_{2} \mathrm{O}$ treatments. Euphytica 171: 283-293

Endo T (1962) Inheritance of anthocyanin concentrations in flowers of Torenia fournieri. Jpn J Genet 37: 284-290

Hammett KRW, Murray BG, Markham KR, Hallett IC (1994) Interspecific hybridization between Lathyrus odoratus and $L$. belinensis. Int J Plant Sci 155: 763-771

Hayashi M, Kato J, Ichikawa Y, Matsubara N, Ohashi H, Mii M (2007a) Inter-sectional hybrids with various ploidy levels between Primula denticulata and three varieties of $P$. modesta. Breed Sci 57: 165-173

Hayashi M, Kato J, Ohashi H, Mii M (2007b) Variation of ploidy levels in inter-section hybrids obtained by reciprocal crosses between tetraploid Primula denticulata $(2 \mathrm{n}=4 \mathrm{x}=44)$ and diploid P. rosea $(2 \mathrm{n}=2 \mathrm{x}=22)$. J Hortic Sci Biotechnol 82: 5-10
Hayashi M, Kato J, Ohashi H, Mii M (2009) Unreduced 3x gamete formation of allotriploid hybrid derived from the cross of Primula denticulata $(4 \mathrm{x}) \times P$. rosea $(2 \mathrm{x})$ as a causal factor for producing pentaploid hybrids in the backcross with pollen of tetraploid P. denticulata. Euphytica 169: 123-131

Horn W, Bundies H, Zimmer K (1976) Untersuchungen zur Züchtung triploider F1-Hybriden bei Lorraine-begonien. $Z$ Pfalnzenzüchtg 76: 177-189

Horn W(2002) Breeding methods and breeding research. In: Vainstein A (ed) Breeding for Ornamental: Classical and Molecular Approaches, Kluwer Academic Publishers, Netherlands, pp 47-83

Horn W (2004) The patterns of evolution and ornamental plant breeding. Acta Hortic 651: 19-31

Hvoslef-Eide AK, Munster C(2006) Begonia, history and breeding. In: Anderson NO (ed) Flower breeding and genetics: issues, challenges and opportunities for the 21st century, Springer, Dordrecht, Netherlands, pp 241-275

Izumikawa Y, Takei S, Nakamura I, Mii M (2008) Production and characterization of inter-sectional hybrids between Kalanchoe spathulata and K. laxiflora (=Bryophyllum crenatum). Euphytica 163: $123-130$

Kato J, Mii M (2000) Differences in ploidy levels of inter-specific hybrids obtained by reciprocal cross between Primula sieboldii and P. Kisoana. Theor Appl Genet 101: 690-696

Kato J, Ishikawa R, Mii M (2001) Different genomic combinations in inter-section hybrids obtained from the crosses between Primula sieboldii (Section Cortusoides) and P. obconica (Section Obconicolisteri) by the embryo rescue technique. Theor Appl Genet 102: 1129-1135

Kopperud C, Einset JW (1995) DNA isolation from Begonia leaves. Plant Mol Biol Rep 13: 129-130

Li Z, Pinkham L, Campbell NF, Espinosa AC, Conev R (2009) Development of triploid daylily (Hemerocallis) germplasm by embryo rescue. Euphytica 169: 313-318

Liu H, Yan G, Sedgley RH (2006) Interspecific hybridization in the genus Leucadendron through embryo rescue. S Afr J Bot 72: $416-420$

Morgan ER, Burge GK, Seelye JF, Hopping ME, Grant JE (1998) Production of inter-specific hybrids between Limonium perezii (Stapf) Hubb. and Limonium sinuatum (L.) Mill. Euphytica 102: 109-115

Murashige T, Skoog F (1962) A revised medium for rapid growth and bio assays with tobacco tissue cultures. Physiol Plant 15: 473-497

Murray MG, Thompson WF (1980) Rapid isolation of high molecular weight plant DNA. Nucleic Acids Res 8: 4321-4325

Nimura M, Kato J, Mii M, Morioka K (2003) Unilateral compatibility and genotypic difference in crossability in interspecific hybridization between Dianthus caryophyllus L. and Dianthus japonicus Thunb. Theor Appl Genet 106: 1164-1170

Oku T, Takahashi H, Yagi F, Nakamura I, Mii M (2008) Hybridization between chocolate cosmos and yellow cosmos confirmed by phylogenetic analysis using plastid subtype identity (PSID) sequences. J Hortic Sci Biotechnol 83: 323-327

Peng CI, Chiang TY (2000) Molecular confirmation of unidirectional hybridization in Begonia $\times$ taipeiensis Peng (Begoniaceae) from Taiwan. Ann Mo Bot Gard 87: 273-285

Peng CI, Chen YK (1991) Hybridity and parentage of Begonia buimontana Yamamoto (Begoniaceae) from Taiwan. Ann Mo Bot Gard 78: 995-1001

Peng CI, Sue CY (2000) Begonia $\times$ taipeiensis (Begoniaceae), a new 
natural hybrid in Taiwan. Bot Bull Acad Sinica (Taiwan) 41: 151-158

Peng CI, Ku SM (2009) Begonia $\times$ chungii (Begoniaceae), a new natural hybrid in Taiwan. Bot Stud (Taipei, Taiwan) 50: 241-250

Reed SM, Jones KD, Rinehart TA (2008) Production and characterization of intergeneric hybrids between Dicjroa febrifuga and Hydranega macrophylla. J Am Soc Hortic Sci 133: 84-91

Sun CQ, Chen FD, Teng NJ, Liu ZL, Fang WM, Hou XL (2010)
Factors affecting seed set in the crosses between Dendranthema grandiflorum (Ramat.) Kitamura and its wild species. Euphytica 171: $181-192$

Tebbitt MC(2005) Begonias: cultivation, identification, and natural history. Timber Press, Portland, OR, USA

USDA (2010) Floriculture Crops 2009 Summary. June 2010

Zeilinga AE (1962) Cytological investigation of hybrid varieties of Begonia semperflorens. Euphytica 11: 126-136 